\title{
Purchase Decision Model: Price Analysis and Brand Awareness Towards Repurchase Interest
}

\author{
Khilyatin Ikhsani \\ Dian Nusantara University, Jakarta, Indonesia
}

\begin{abstract}
This study aims to determine the effect of price and brand awareness on purchasing decisions and repurchase interest. This research design is explanatory. The sampling technique in this study was at Dian Nusantara University students who had consumed Janji Jiwa Coffee and filled out a questionnaire using purposive sampling method but still met the predetermined criteria. The population of 307 students at the University of Dian Nusantara Tanjung Duren, Management Study Program. Using the Slovin formula, a sample of 100 students was obtained. The methods used Quantitative analysis SEM analysis tools and Smart-PLS 3.0 tools. The results of this study found that price has positive and significant effect on purchasing decisions, brand awareness has positive and significant effect on purchasing decisions, price has positive and significant effect on repurchase interest, brand awareness has positive and significant effect on repurchase interest, and purchase decisions has positive and significant effect on repurchase interest.
\end{abstract}

Keywords: Purchase Decision, Repurchase Interest, Price, Brand Awareness

DOI: $10.7176 / \mathrm{JMCR} / 73-02$

Publication date: November $30^{\text {th }} 2020$

\section{Introduction}

The increasing of coffee shops in several regions in Indonesia can indicate that the presence of coffee in Indonesia is currently popular. This phenomenon is the result of modernization which changes not only lifestyles, but also thought patterns and cultural values. The need for self-actualization is also one of the phenomena of changing the lifestyle of today's society. This is not a negative thing, but a stepping stone from the development of the coffee shop business in Indonesia (Said, 2017). Many coffee shops are competing to offer the taste of Indonesian local coffee. As the coffee industry increases, this makes coffee a lifestyle for most of the people today. One of the popular coffee shops for coffee lovers is Janji Jiwa.

Now along with the development of time, there are various brands of coffee drinks from coffee shops on the market. Competitive products are increasing in number. The emergence of new brands has intensified competition among existing brands. The variety of coffee drink brands from coffee shops on the market causes consumers to be more selective in choosing the products to consume.

Table 1. Coffee Price List in Coffee Shop

\begin{tabular}{ll}
\hline Coffee & Price (Rp) \\
\hline Kenangan & 18,000 \\
Janji Jiwa & 18,000 \\
Kulo & 15,000 \\
Fore & 21,000 \\
\hline \multicolumn{2}{c}{ Source: processed by researchers }
\end{tabular}

Price is the main factor influencing buyers' choice. Consumers will be faced with a choice of competing products with various prices. This results in price competition from various competing products. This price can be a consideration for consumers when making a purchase decision by comparing prices with the same category.

Even though Janji Jiwa has implemented a strategy to create brand awareness for customers, it is still inferior to Kenangan for the coffee shop category at the Top Brand Awards according to the following data:

\begin{tabular}{|lll|}
\hline BRAND & TBI 2020 & \\
\hline Kenangan & $39.9 \%$ & TOP \\
Janji Jiwa & $29.8 \%$ & TOP \\
Kulo & $13.6 \%$ & TOP \\
Fore & $5.1 \%$ & \\
Furo & $3.1 \%$ & \\
\hline
\end{tabular}

Figure 1. Top Brand Index 2020

Source: https://www.topbrand-award.com/top-brand-index/, accessed April 2020

From Figure 1, it can be seen that Kopi Kenangan is the market leader in the top brand index with a TBI value of $39.9 \%$. Meanwhile, Janji Jiwa came in the second with a TBI score of $29.8 \%$. The third is Kulo with a 
TBI value of $13.6 \%$, then Fore, with a TBI score of $5.1 \%$, and Furo, with a TBI score of $3.1 \%$.

This shows that the the more often a consumer buys and uses a product, the higher their brand awareness for that product. After a brand has brand awareness, consumers will make the brand tobe their preference and ultimately influence the purchase decision for a product and its implications can affect repurchase interest.

\section{Theoritical Review}

\subsection{Repurchase Interest}

Repurchase interest is a positive attitude of consumers towards sellers which will result in repeat purchases, Suhaily, L., \& Soelasih, Y. (2017). Repurchase interest is the stage of the consumer's tendency to act before the buying decision is actually implemented, Kotler and Keller (2009: 235). Repurchase interest is a behavior that appears in response to objects that indicate a customer's desire to make repeat purchases, Putri, JN (2018). According to Goh et al. (2016) repurchase interest can be defined as a buyer's willingness to repurchase the same brand or product according to good experiences and fulfilled expectations. Repurchase interest is perceived as an individual assessment of repeated purchases from the same company or brand, Astuti, DY (2018).

According to Fang et al. (2014) repurchase interest is a purchase interest based on past purchasing experience. Phuong, NND, \& Dai Trang, TT (2018) define repurchasing as a motivational level for a consumer to repeat purchasing behavior on a product. Kotler and Armstrong (2015: 135-150), the main factors that influence a person's interest in making repeat purchases are: 1) Cultural factors, 2) Psychological factors, 3) Personal factors, 4) Social factors.

\subsection{Purchase decision}

Purchase decisions are the actions of consumers to want to buy or not to buy products, Kotler (2002: 82). Indicators of purchasedecision process, namely: the purpose of buying a product, processing information to get to brand selection, stability in a product, providing recommendations to others, making repurchases, Kotler (2012: 36). Consumer purchase decision can be defined as a mental orientation that characterizes the consumer's approach to making choices, Diana-Rose, F., et al. (2016). Purchase decision is a process where consumers recognize the problem, seek information about a particular product or brand and evaluate how well each of these alternatives can solve the problem, which then leads to a purchase decision, Tjiptono (2008: 21). Purchase decisions are made by consumers based on an evaluation of various criteria, Gama, AWS et al. (2018).

Purchase decision according to Kotler and Keller (2013: 192) is a consumer's decision to buy after evaluating several factors such as brand, location of purchase, amount to be purchased, time of purchase, and methods of payment that can be made. Purchase decision process that a customer goes through when buying a product. this can be seen as a specific form of cost-benefit analysis, Peng, WS (2016). The dimensions of the purchasing decision variable used in this study are based on theoretical studies according to Kotler and Keller (2012: 171) are: a) Product Selection, b) Brand Selection, c) Purchase Channel Selection, d) Purchase Time, and e) Purchase Amount.

\subsection{Price}

Hapzi Ali, et.al (2017) Price is one of the critical success factors for a company because price determines how much profit the company will get from selling its products in the form of goods or services. According to Kotler and Armstrong (2008: 62), price is defined as something that is given or sacrificed to get a service or product. According to Kotler and Armstrong (2008: 62) the dimensions of price include: a) affordability of prices, b) suitability of price with product quality, c) competitive prices, and d) compatibility of prices with benefits.

\subsection{Brand Awareness}

Brand awareness refers to the level of consumer recognition, acceptance and recall of a brand in any case, Bilgin, Y. (2018). Karam \& Saydam (2015) said that brand awareness has turned into an important variable that affects customer perceptions of a brand. Achievement in brand management arises from understanding and properly monitoring brand image and loyalty to create strong characteristics that will influence consumers when making decisions. Brand awareness is very important in any business, including the knitting industry because it not only invites consumers to buy but can make consumers become repeat customers. Consumers are more likely to buy goods or use services from a name that they trust and are easily recognizable, so that what brand comes to consumers' minds first, they are more likely to buy the brand and tell others about the brand, Oktaviani, F. , \& Rustandi, D. (2018).

Brand awareness is related to the strength of brand recognition or an impression on the memory, as reflected in the ability of consumers to recognize meek in different conditions, Sitinjak (2006: 56). The dimension of Brand Awareness according to Sitinjak (2006: 56) describes how to create value as follows, how brand awareness works to help brands can be explained by how brand awareness creates value. Then the dimensions of brand awareness are as follows: a) anchor to which other association can be attacked, b) 
familiarity-linking, c) substance / commitment, and d) Brand to consider.

Based on the research formulation, research objectives, literature review, previous research and research rood map, the framework for this research for internal research is as shown in Figure 2 below.

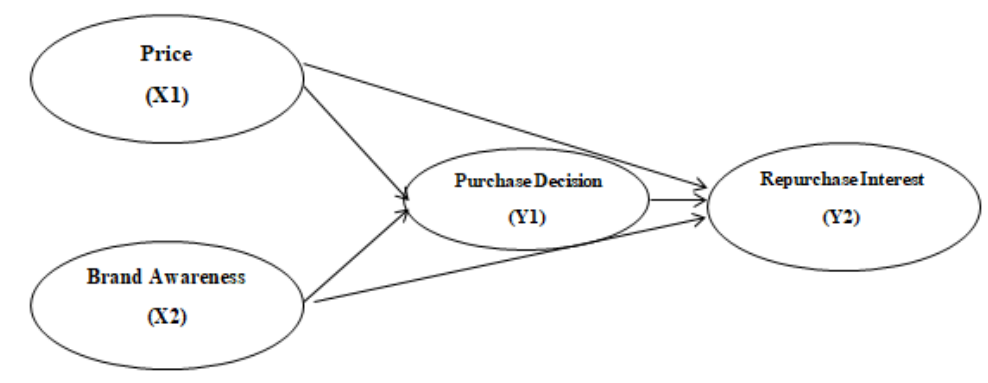

Hypothesis

Figure 2. Framework for thinking

Based on the research objectives, the research hypothesis is as follows:

1) H1: Price has positive and significant effect on PurchaseDecision at Janji Jiwa coffee shop for students of Universitas Dian Nusantara.

2) H2: Brand awareness has positive and significant effect on Purchase Decision at Janji Jiwa coffee shop for students of Universitas Dian Nusantara.

3) H3: Price has positive and significant effect on Repurchase Interest at Janji Jiwa coffee shop for students of Universitas Dian Nusantara University.

4) H4: Brand awareness has positive and significant effect on Repurchase Interest at Janji Jiwa coffee shop for students of Universitas Dian Nusantara.

5) H5: Purchase Decision has positive and significant effect on Repurchase Interest at Janji Jiwa coffee shop for students of Universitas Dian Nusantara.

\section{Research Method}

\subsection{Research Objects and Instruments}

This research was conducted in Dian Nusantara University students, with case study on respondents who have ever consumed Janji Jiwa coffee.T he research had conducted for 6 months in one academic year from January to June 2020. The instrument used was a questionnaire using a Likert scale with a score of 1-5 which was expressed from the most negative, neutral to the most positive.

\subsection{Methods and Analysis Tools}

The method of analysis of this research is quantitative methods and analysis tools with SEM Before being analyzed with Path analysis, the instrument test (questionnaire) is first tested with validity and reliability and hypothesis testing with alpha 10 percent $(0.1)$. Price and brand awareness as independent variables, purchase decision as an intervening variable and repurchase interest as the dependent variable. To test the intervening variables, path analysis methods are used, such as the extension of multiple linear regression analysis. The population in this study was students of Dian Nusantara University, Management study program, total 307 students. The research sample obtained was 100 respondents, using nonprobability sampling technique. The data analysis method in this research is SEM with the help of softwareSmart-PLS 3.0.

\section{Results And Discussion}

\subsection{Result}

From the SmartPLS output results, all constructs have a composite reliability value above 0.70 . So it can be concluded that the construct has good reliability. The measurement model for the validity and reliability test, the model determination coefficient and the path coefficient for the equation model, can be seen in the following figure: 


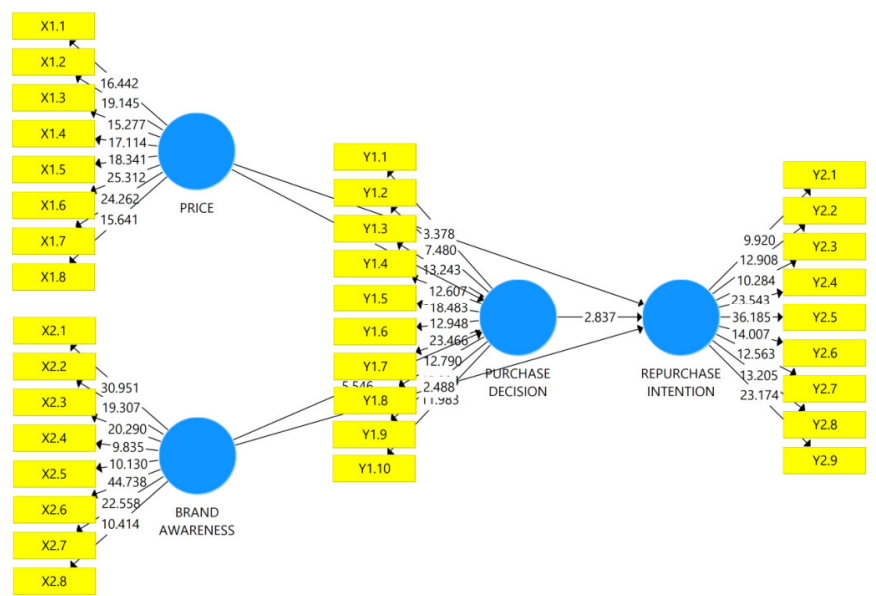

Figure 3. PLS Algorithm Results

Source:Primary data, processed in 2020

The structural model in PLS is evaluated using R2 for the dependent variable and the path coefficient value for the independent variable, which is then assessed for its significance based on the t-statistic value for each path. The structural model of this research can be seen in the following figure:

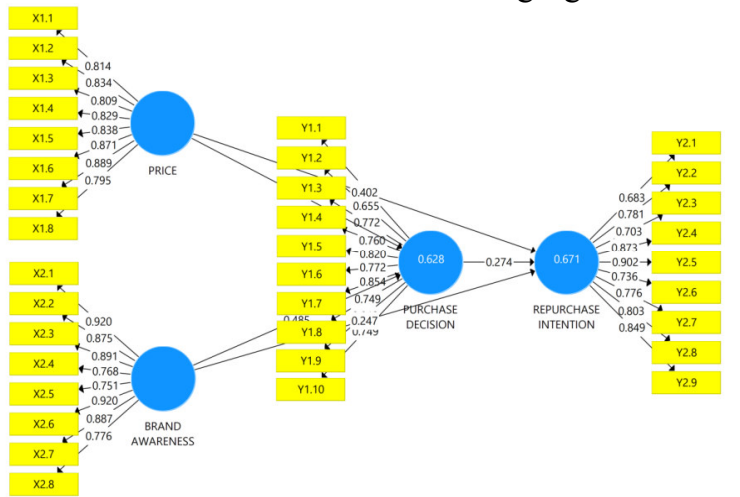

Figure 4. PLS Bootstrapping Result

Source: Primary data, processed in 2020

$R$ value for each endogenous variable in this study can be seen in the table:

Table 2. R-square

\begin{tabular}{lcc}
\hline Variable & $\boldsymbol{R}$ Square & $\boldsymbol{R}$ Square Adjusted \\
\hline Purchase Decision (Y1) & 0.628 & 0.620 \\
Repurchase interest (Y2) & 0.671 & 0.660 \\
\hline
\end{tabular}

Source: Data processing with PLS, 2020

Based on the results of the above calculations, the Q-Square value is 0.987 . This shows the large diversity of research data that can be explained by the research model is $98.7 \%$, while the remaining $1.3 \%$ is explained by other factors that are outside of this research model. Based on these results, the model in this study can be stated as having a very good goodness of fit.

The results of the calculation of the effect between variables are shown in the table below.

Table 3. Path Coefficients (Mean, STDEV, t-Value)

\begin{tabular}{lcccc}
\hline \multicolumn{1}{c}{ Variable } & $\begin{array}{c}\text { Original Sample } \\
\text { (O) }\end{array}$ & T Statistics & P Values & $\begin{array}{c}\text { Significance } \\
\text { Level }\end{array}$ \\
\hline Price -> Purchase Decision & 0.397 & 5,088 & 0.000 & $<0.05$ \\
Brand Awareness - P Purchase decision & 0.485 & 2,488 & 0.000 & $<0.05$ \\
Price -> Repurchase Interest & 0.402 & 3,378 & 0.005 & $<0.05$ \\
Brand awareness - > Repurchase Interest & 0.247 & 2,488 & 0.000 & $<0.05$ \\
Purchase Decision -> Repurchase Interest & 0.274 & 2,837 & 0.005 & $<0.05$ \\
\hline
\end{tabular}

Source:Primary data, processed in 2020

Based on the table above, it can be seen that the measurement model formed is Equation model as below:

1. Price has positive direction coefficient towards purchase decision.

2. Brand awareness has positive direction coefficient towards purchase decision.

3. Price has positive direction coefficient towards repurchase interest. 
4. Brand awareness has positive direction coefficient towards repurchase interest.

5. Purchase decision has positive direction coefficient towards repurchase interest.

Table 4. Hypothesis test

\begin{tabular}{lllll}
\hline Hypothesis & Influence & t-Count & P-Value & Result \\
\hline H1 & Price affects on purchase decision & 5,088 & 0.000 & Proven \\
H2 & Brand awareness affects on purchase decision & 2,488 & 0.000 & Proven \\
H3 & Price affects on Repurchase Interest & 3,378 & 0.005 & Proven \\
H4 & Brand awareness affects on repurchase interest & 2,488 & 0.000 & Proven \\
H5 & Purchase decision affects on repurchase interest & 2,837 & 0.005 & Proven \\
\hline
\end{tabular}

Source: Primary data, processed in 2020

\subsection{Discussion}

\subsubsection{The effect of price on purchase decision}

Based on table above the price variable (X1) has positive and significant effect on purchase decision variable (Y1). This shows that the price offered by Janji Jiwa coffee shops is in accordance with the benefits received by consumers so that it has an impact on purchase decision of Janji Jiwa coffee products.

This is supported by previous research: Deebhijarn (2016), Ali and Anggita (2017), Hafiz et al. (2017), Camelia et al. (2017), Quansah (2015), Hustić and Gregure (2015), that price has positive and significant effect on purchase decision.

\subsubsection{The effect of brand awareness on purchase decision}

Based on table above that brand awareness variable (X2) has positive and significant effect on purchase decision variable (Y1). This shows that brand awareness of Janji Jiwa coffee is in the minds of consumers so that they can make purchase decision.

This is supported by previous research: Ambolau et al. (2015), Krisnawati (2016), Sunaryo and Sudiro (2018), Sawagvudcharee et al. (2018), Saragih (2018), that brand awareness has positive and significant effect on purchase decisions.

\subsubsection{The effect of price on repurchase interest}

Based on table above price variable (X1) has positive and significant effect on repurchase interest variable (Y2). This shows that price offered by Janji Jiwa coffee shop is in accordance with the benefits received by consumers. If consumers have felt the benefits, it will have an impact on repurchase interest Janji Jiwa coffee products. Price is defined as something that is given or sacrificed to get a service or product.

This is supported by previous research: Ilat et al. (2018), Putri (2016), Sartika (2017), Adiputra and Sutopo (2016), Lutfi (2017), that Price has positive and significant effect on Repurchase Interest.

\subsubsection{The effect of brand awareness on repurchase interest}

Based on table above brand awareness variable (X2) has positive and significant effect on repurchase interest variable (Y2). This shows that Janji Jiwa coffee brand has been widely recognized by consumers who have made purchase decision and can have a repurchase interest. In addition, a good reputation from a company that produces quality coffee can also influence the repurchase interest.

This is supported by previous research: Immawati (2018), Halim (2017), Huda et al (2020), Izzudin and Novandari (2018), that Brand Awareness has positive and significant effect on Repurchase Interest.

\subsubsection{The influence of purchase decision on repurchase interest}

Based on table above purchase decision variable (Y1) has positive and significant effect on repurchase interest variable (Y2). This shows that the purchase decision will make consumers have an interest in repurchasing interest. Therefore, the things that influence consumers in evaluating several brands before making a purchase decision and making a choice of the Janji Jiwa coffee brand compared to other brands in the market with the same category, namely coffee in the shop must be considered and improved so that consumers may have repurchase interest.

This is supported by previous research: Cahyadi and Kodrat (2016), Dewi et al. (2015), Suyanti et al. (2020), Suryana and Dasuki (2013), that Purchase Decision has positive and significant effect on Repurchase Interest.

\section{Conclusions And Suggestion}

\subsection{Conclusions}

Based on the results of the discussion, it can be concluded as follows:

1) Price has positive and significant effect on purchase decision.

2) Brand awareness has positive and significant effect on purchase decision.

3) Price has positive and significant effect on repurchase interest.

4) Brand awareness has positive and significant effect on repurchase interest.

5) Purchase decision has positive and significant effect on repurchase interest. 


\subsection{Suggestions}

\subsubsection{Suggestions for Company}

Some of the things suggested by researchers based on the results of research to Jiwa Group are:

1) In order to increase purchase decision and repurchase interest through prices, Jiwa Group is advised to pay attention to the following points; a) to evaluate the affordability of prices; b) to pay attention to price suitability with product quality; c) to increase price competitiveness; and d) to pay attention to price suitability with benefits.

2) In order to increase purchase decision and repurchase interest through brand awareness, Jiwa Group is advised to pay attention to the following points; a) to increase the anchor of consumer brand awareness; $b$ ) to increase awareness of familiarity linking of Janji Jiwa coffee products; c) to maintain Jiwa Group's commitment; and d) to increase brand awareness to consider consumers.

3) In order to improve purchase decision, Jiwa Group is advised to pay attention to the following points; a) to pay attention to the suitability of the price offered with the benefits that will be obtained by consumers, b) to increase brand awareness of Janji Jiwa products in the community, c) to improve product quality, d) to expand the distribution channels of Janji Jiwa coffee products, e) to pay attention to the timing of product sales, and f) to prepare and to pay attention to the suitability of the amount of stock offered with the needs of consumers.

4) To increase repurchase interest of consumer, Jiwa Group is advised to pay attention to the following points; a) to pay attention to the suitability of the price offered with the benefits that will be obtained by consumers, b) to increase brand awareness of Janji Jiwa products in the community, and c) to pay attention to things that affect purchase decision so as to increase consumer repurchase interest in Janji Jiwa coffee products.

\subsubsection{Suggestions for Future Research}

These are the things suggested by researchers for the next research are:

1) To obtain comparisons and strengthen the theory of the effect among the variables studied, it is necessary to carry out research or review at different locations that sell Janji Jiwa coffee products with different populations.

2) As stated in the conclusion above, the variable price and brand awareness have an effect of $62,8 \%$ of the purchase decision, meaning that there are still $37.2 \%$ which is another factor that affects the purchasing decision of Janji Jiwa coffee products. In addition, the purchase decision, price, and brand awareness variables have an effect of $67,1 \%$ of the repurchase interest shows a double correlation, meaning that there is still $32.9 \%$ which is another factor affecting the repurchase interest of Janji Jiwa coffee products.

\section{REFERENCES}

Adiputra, F., \& Sutopo, S. (2016). Analysis of the Influence of Satisfaction and Price Perception on Restaurant Image and Customer Repurchase Interest at Holycow Semarang. Diponegoro Journal of Management, 5363.

Ali, Hapzi, Anggita, Rizza. (2017). The Influence of Product Quality, Service Quality and Price to Purchase Decision of SGM Bunda Milk (Study on PT. Sarihusada Generasi Mahardika Region Jakarta, South Tangerang District). Sch. Bull, Vol-3, Iss-6 (Jun, 2017): 261-272.

Astuti, DY (2018). The Effect of Promotion Prices on Repurchase Interest in the Evaluation of Starbucks Coffee Buyers in Yogyakarta. Essay.

Bilgin, Y. (2018). The effect of social media marketing activities on brand awareness, brand image and brand loyalty. Business \& Management Studies: An International Journal, 6 (1), 128-148.

Cahyadi, M., \& Kodrat, DS (2016). The Impact of Product Quality and Price on the Decision of Consumer Purchase Which Affects the Consumer Repurchase Intention at Pentol Bonbon Company. The Third International Conference on Entrepreneurship. Vol. 1, Pages 235-247

Camelia, Savira Bintang, Suryoko, Sri. (2017). The Effect of Variety Menu, Price, and Brand Image Toward the Purchasing Decision (A Case Study on the Consumer D'Cost Seafood Restaurant Semarang). Diponegoro Journal Of Social And Political Year 2017, Pages 1-7.

Deebhijarn, Samart. (2016). The Marketing Mix Strategy Model to Influencing the Decision to Purchase Readyto-Drink (RTD) Green Teas among University Students in Bangkok Metropolitan Region, Thailand. International Journal of Sciences: Basic and Applied Research (IJSBAR) (2016), Vol 29, No. 1.

Dewi, DR, Magdalena, MM, Dhiana, Patricia. (2015). The Influence of Word Of Mouth, Income Level And Product Quality On Purchasing Decisions That Have An Impact On Consumer Repurchase Interest (A Case Study On Milkfish Juwana Elrina Semarang). Journal of Management. Vol. 1, No. 1, pp. 1-19

Diana-Rose, F., Zariyawati, MA, Norazlina, K., Annuar, MN, \& Manisah, O. (2016). Consumers' purchasing decision towards food products of small and medium enterprises. International Review of Management and Marketing, 6 (4). 
Fandy Tjiptono. 2008. Marketing Strategy, Second Edition, First Edition Jakarta: Andi Offset.

Fang, Y., Qureshi, I., Sun, H., McCole, P., Ramsey, E., \& Lim, KH (2014). Trust, satisfaction, and online repurchase intention. Mis Quarterly, 38 (2), 407-A9.

Gama, AWS, Rustiarini, NW, \& Anggraini, NPN (2018). Imaging and Purchasing Decision in Traditional Art Market. International research journal of management, IT and social sciences, 5 (2), 175-185.

Goh, SK, Hak, MFA, Tee, PL 2016. Determinants of Smartphone Repeat Purchase Intention Among Dieting: A Moderations Role of Social Influence and a Mediating Effect of Consumer Satisfaction. Internal Review of Management \& Marketing. 6 (4), 993-1004.

Hafiz, Putra, et. al. (2017). Analysis on Factors Influencing Purchase Decision on Mangosteen Skin Extract Garcia. International Journal of Science and Research (IJSR), Vol. 6, Issue 8.

Halim, AV (2017). The influence of brand awareness, brand association, brand loyalty, perceived quality, on the intention to repurchase Nestle Pure Life drinks (Doctoral dissertation, Tarumanegara University).

Huda, IU, Karsudjono, A., \& Darmawan, R. (2020). The Influence of Store Atmosphere and Brand Awereness on Consumer Repurchase Interest at 88 Banjar Indah Permai Coffee Shop through Customer Satisfaction. Journal of Management Partners, 4 (4), 492-508.

Hustić, Ivana; Gregure, Iva. (2015). The influence of price on customer's purchase decision. Central European Conference on Information and Intelligent. Central European Conference on Information and Intelligent.

Ilat, LV, Murni, S., \& Tommy, P. (2018). Analysis of the Effect of Product and Price on Repurchase Decisions at Sme D'cendol 77 in Eic Unsrat. Journal of EMBA: Journal of Economic Research, Management, Business and Accounting, 6 (4).

Immawati, SA (2018). Product Packaging Design and Advertising Appeal to Brand Awareness and Its Impact on Sosro Bottle Tea Buy-back Interest for Students at the University of Muhammadiyah Tangerang. In Proceedings of the Unimus National Seminar (Vol. 1).

Izzudin, MS, \& Novandari, W. (2018). The Effect Of Perceived Quality, Brand Image On Customer Satisfaction And Brand Awareness Toward Repurchase Intention. Journal Of Research In Management, 1 (3).

Karam, AA, \& Saydam, S. (2015). An Analysis Study Of Improving Brand Awareness And Its Impact On Consumer Behavior Via Media In North Cyprus (A Case Study Of Fast Food Restaurants). International Journal Of Business And Social Science. 6 (1) .66-80.

Kotler, Philip. (2002). Marketing Management, Millennium Edition, Volume 2. Jakarta: PT Prenhallindo.

Kotler, Philip and Armstrong Gary. 2008. Principles of Marketing First Impression. Prentice Hall Inc, New Jersey.

2015. Principles of Marketing. Prentice Hall Global. PT. Prenhallindo. Jakarta.

Kotler, Philip., Keller, Kevin L. (2013). Marketing Management, Second Volume. Jakarta: Erlangga. (2012). Marketing Management 14 th edition. Jakarta: PT. Gramedia Group Index.

Kotler, Philip., Keller, Kevin L. (2009). Marketing Management. Volume I. Edition 13. Jakarta: Erlangga.

Krisnawati, Devi. (2016). The influence of brand awareness on purchasing decisions for the Aqua brand bottled water (Study on the community in the city of Bandung). Krisnadwipayana Journal of Business Management, Vol. 4, No. 1

Lutfi, I. (2017). The Influence of Product Quality and Price on Buyback Interest of Juwana Vaccum Milkfish through Customer Satisfaction as an Intervening Variable (Study on Customers of PT. Bandeng Juwana Elrina Semarang) (Doctoral dissertation, Diponegoro University).

Oktaviani, F., \& Rustandi, D. (2018). Digital Marketing Implementation in Building Brand Awareness. Public Relations Department, 3 (1), 1-20.

Peng, WS (2016). The Influence Of Brand Equity Towards Purchasing Decision Of Dietary Supplement Products In Zhengzhou China (A Case Study Of Amway) (Doctoral dissertation, President University)

Permana Ambolau, Muhammad Arie, et. al. (2015). The Influence of Brand Awareness And Brand Image On Purchase Decision. Journal of Business Administration (JAB), Vol. 2, No. 2.

Phuong, NND, \& Dai Trang, TT (2018). Repurchase intention: The effect of service quality, system quality, information quality, and customer satisfaction as a mediating role: a PLS approach of m-commerce ride hailing service in Vietnam. Marketing and Branding Research, 5 (2), 78.

Daughter, JN (2018). Analysis of Factors Affecting Wardah's Cosmetics Repurchase Interest (Empirical Study on Students of the Muhammadiyah University of Surakarta) (Doctoral dissertation, Muhammadiyah University of Surakarta).

Daughter, LH (2016). Factors Affecting Consumer Repurchase Interest of Delicy Naget Products. PERFORMANCE, 1 (2), 162-170.

Quansah, Fidelis. (2015). Factors Affecting Ghanaian Consumers' Purchasing Decision of Bottled Water. International Journal of Marketing Studies, Vol. 7, No. 5. 
Said, I. (2017). Coffee Shop and Modern Lifestyle. Al-Khitabah Journal, Vol. III, No. 1, 33-47.

Saragih, MG (2018, October). Analysis of Brand Awareness and Brand Trust to Purchase Decision (Case Study: PT. MountAqua Kruenggukuh, AcehProvince). In International Conference of ASEAN Prespective and Policy (ICAP) (Vol. 1, No.1, pp. 69-74).

Sartika, D. (2017). Analysis of Factors Affecting Purchase Intention of YOU C 1000 Products and Their Impact on Consumer Loyalty. Journal of Economics and Business Research, 2 (1), 10-21.

Sawagvudcharee, O., Shrestha, S., \& Mandal, S. (2018). Impacts of Brand on Consumer Decision Making: Case Study of Beer Brands in Nepal. International Journal of Research, 5 (16).

Sitinjak, Durianto Sugiarto. 2006. Marketing Management in Indonesia: Strategy to Conquer the Market. Gramedia Jakarta.

Sitinjak, Tumpal JR. 2006. Operations Research for Managerial Decision Making Using Excel Applications. Yogyakarta: Graha Science.

Sugiyono. (2013) Quantitative, Qualitative and R \& D Research Methods. Bandung: Alfabeta

Sugiyono. (2015) Bandung Business Research Methods: Alfabeta.

Suhaily, L., \& Soelasih, Y. (2017). What Effects Repurchase Intention of Online Shopping. International Business Research, 10 (12), 113-12.

Sunaryo, S., \& Sudiro, SEA (2018). The Impact of Brand Awareness on Purchase Decision: Mediating Effect of Halal Logo and Religious Beliefs on Halal Food in Malang Indonesia. Australasian Journal of Islamic Finance and Business (AJIFB), 4 (1), 28-37.

Suryana, Popo \& Dasuki, E., S. (2013). Analysis of Factors Affecting Purchasing Decisions and Their Implications on Repurchase Interest. Trichonomics. Volume 12, No. 2. p 190-200

Suyanti, W., Achmad, GN, \& Wasil, M. (2020). The Influence of Packaging and Television Advertising on Purchasing Decisions and Its Implications for Floridina Repurchase Interest (Study on Students of the Faculty of Economics and Business, University of Mulawarman Samarinda). Mulawarman Journal of Management Science (JIMM), 4 (3).

https://www.merdeka.com/gaya/kopi-janji-jiwa-kantungi-rekor-muri-buka-700-gerai-dalam-setahun.html (Accessed May 2020) 